\title{
SOCIAL REPRESENTATIONS OF LOW-INCOME DIABETIC WOMEN ACCORDING TO THE HEALTH-DISEASE PROCESS
}

\author{
Denise Siqueira Péres ${ }^{1}$ \\ Laércio Joel Franco ${ }^{2}$ \\ Manoel Antônio dos Santos ${ }^{3}$ \\ Maria Lúcia Zanetti
}

Peres DS, Franco LJ, Santos MA, Zanetti ML. Social representations of low-income diabetic women according to the health-disease process. Rev Latino-am Enfermagem 2008 maio-junho; 16(3):389-95.

The purpose of this article is to identify the social representations of low-income diabetic women according to the health-disease process. This is a descriptive, exploratory study. Eight participants, all of them patients at a basic health unit in Ribeirão Preto, were interviewed in 2003. The data were organized according to thematic content analysis and analyzed according to theory of social representations. Diabetes is related to negative feelings, such as shock, anger and sadness; the diet plan is linked to the loss of pleasure, and also to health risks. The diabetic women showed an ambivalent relation to medication, perceived it as both tiring and as a resource that promotes well-being and improvements in quality of life. The negative representation of health services seems to interfere with the behavior of adherence to pharmacological treatment. Understanding the representations of women with diabetes contributes to integral healthcare for diabetic patients.

DESCRIPTORS: diabetes mellitus; health-disease process; health educación

\section{REPRESENTACIONES SOCIALES DE LAS MUJERES DIABÉTICAS DE CLASES POPULARES EN LO REFERENTE AL PROCESO SALUD Y ENFERMEDAD}

Este trabajo tiene como objetivo identificar las representaciones sociales de mujeres diabéticas de clases populares en relación al proceso salud-enfermedad. Se trata de un estudio descriptivo y exploratorio. Fueron entrevistadas ocho participantes, atendidas en una unidad básica de salud del municipio de Ribeirao Preto, en 2003. Los datos fueron organizados mediante un análisis temático de contenido y analizados según la teoría de las representaciones sociales. La diabetes está relacionada a sentimientos negativos, como choque, rabia y tristeza; el plano alimentario aparece vinculado a la pérdida del placer y de daños a la salud. Las mujeres diabéticas mostraron una relación ambivalente con el uso de los medicamentos, percibido como productor de cansancio y como un recurso que promueve el bienestar y mejora la calidad de vida. La representación negativa de los servicios de salud parece interferir en el comportamiento de adherencia al tratamiento con medicamentos. Comprender las representaciones de mujeres con diabetes contribuye a la prestación de servicios del cuidado al diabético.

DESCRIPTORES: diabetes mellitus; processo salud enfermedad; educación en salud

\section{REPRESENTAÇÕES SOCIAIS DE MULHERES DIABÉTICAS, DE CAMADAS POPULARES, EM RELAÇÃO AO PROCESSO SAÚDE-DOENÇA}

Este trabalho tem como objetivo identificar as representações sociais de mulheres diabéticas das camadas populares em relação ao processo saúde-doença. Trata-se de estudo descritivo e exploratório. Foram entrevistadas oito participantes, atendidas numa unidade básica de saúde do município de Ribeirão Preto, SP, em 2003. Os dados foram organizados mediante análise temática de conteúdo e analisados segundo a teoria das representações sociais. O diabetes está relacionado a sentimentos negativos como choque, revolta e tristeza, o plano alimentar aparece vinculado à perda do prazer e prejuízos à saúde. As mulheres diabéticas mostraram relação ambivalente com o uso da medicação, percebido como cansativo e como recurso que promove o bem-estar e melhoria da qualidade de vida. A representação negativa dos serviços de saúde parece interferir no comportamento de adesão ao tratamento medicamentoso. Compreender as representações de mulheres com diabetes contribui para a integralidade do cuidado ao diabético.

DESCRITORES: diabetes mellitus; processo saúde-doença; educação em saúde

\footnotetext{
${ }^{1}$ M.Sc. in Medical Sciences, e-mail: desiperes@ig.com.br; ${ }^{2}$ Full Professor, e-mail: Ifranco@ig.com.br. University of São Paulo at Ribeirão Preto Medical School, Brazil; ${ }^{3}$ Ph.D., Faculty, University of São Paulo at Ribeirão Preto School of Philosophy, Sciences and Languages, Brazil, e-mail: masantos@ffclrp.usp.br; ${ }^{4}$ Associate Professor, University of São Paulo at Ribeirão Preto College of Nursing, WHO Collaborating Centre for Nursing Research Development, Brazil, email: zanetti@eerp.usp.br
} 


\section{INTRODUCTION}

Diabetes mellitus is a chronic disease, and one of the priorities in worldwide public healthcare. Patients affected by diabetes demand education for self-care and continuous supervision for long periods of time. As such, it is important to highlight the need of follow-up, support and continuous care by a multiprofessional healthcare team, as two large studies showed in the $1990 \mathrm{~s}^{(1-2)}$.

Particularly based on these two studies, the importance of multi-professional healthcare work for diabetes patient education was acknowledged. Also, countless educational programs have been developed in Brazil as well as abroad ${ }^{(3-4)}$.

However, for a program to be effective, healthcare professionals' and patients' concepts about the health-disease process need to be taken into account, along with other factors. Health-disease conceptions have characteristics that vary according to the socio-cultural context ${ }^{(5)}$, i.e. the way in which the subjects interpret health is part of a series of conceptions, values and experiences shared by people participating in the same culture.

Diabetes patients' illness experience partially depends on what is understood as health and, as such, the meanings of health-disease are not always the same for professionals and diabetic users of healthcare services. Patients with diabetes have representations and popular healthcare practices which they exchange quite often in daily experiences. It is also common for healthcare teams to ignore these kinds of popular knowledge that are commonly circulated, considering technical-scientific knowledge as the only valid and correct knowledge ${ }^{(6)}$.

Professionals and diabetic users are sometimes incapable of "speaking the same language", and popular knowledge and representations may end up being disregarded ${ }^{(7)}$. The biomedical knowledge area usually rejects the experience and know-how of people going through a disease and, as such, science is often considered as the only valid and correct knowledge ${ }^{(8)}$. The legitimacy of biomedical knowledge as the only valid knowledge implies disregarding any other knowledge types, frequently shared by women with diabetes. Therefore, recovering this female knowledge is a task imposed on anyone interested in the forgotten voices from our collective memory.
Since the representations of lower-income masses on the health-disease process are usually different from the conceptions that the professionals have, it is fundamental to understand them to assure more effective interventions ${ }^{(5)}$. The literature available in this area is still incipient, which justifies new studies dedicated to understanding the process of social construction of these representations in people with diabetes. Therefore, the purpose of the present study is to identify the social representations of diabetic women from lower-income populations, in relation to the health-disease process.

\section{THEORETICAL REFERENCE}

The theory of social representations elaborated by Moscovici ${ }^{(6)}$ was chosen as the theoretical reference framework. This theory proposes the valuation of lay knowledge and everyday knowledge, along with their processes of production - those that develop within the collective context - and appropriation - those that happen within each individual's experience through an operation named anchoring, which allows the scientific knowledge to be assimilated by popular knowledge.

The study of social representations is associated to understanding the body, health and diseases as a matrix of meanings. The appropriation of this theory in health studies is relevant because it incorporates the psychosocial aspects associated to diseases. This may promote reflections about the treatment modes and strategies professionals use most often in the context of the new healthcare paradigm, which highlights the need for care while considering the subject's integrality.

This theory is found to be at the border between the psychological and the social, seeking to catch the psychological and social dimension of the phenomena. This makes it particularly valuable in the healthcare area, especially when a position that values knowledge originating in common sense and the perspective of healthcare service users are adopted.

\section{THE METHODOLOGICAL ROUTE}

It is a descriptive, exploratory study, with a qualitative research focus, performed in January/2003 at a Basic Healthcare Unit (BHU) in the North of 
Ribeirão Preto-SP, Brazil. This Unit is situated in a low-income neighborhood, and its service area covers several peripheral neighborhoods of the city.

First, medical records of people diagnosed with diabetes who were registered at the BHU were collected. The records of male users were disregarded. Participants were selected at random from records of patients who fit the following inclusion criteria: type-2 diabetic women who had been diagnosed at least 12 months before, users of one of the public healthcare services in the Ribeirão Preto network, capable of communication and dialogue, and who agreed to participate in the study.

Each of the selected subjects was contacted through a phone call or letter, explaining the purposes of the research and scheduling convenient dates and times for their presence at the BHU. After signing the Term of Consent, the interviews were started in rooms with adequate conditions of privacy. The criterion of data saturation ${ }^{(10)}$ was used to determine the number of participants, resulting in eight interviews. The interviews were recorded in audio and each took about 60 minutes. The data from each interview were subsequently transcribed, integrally and literally, making up the corpus of the study. The empirical data were organized according to the Thematic Content Analysis technique ${ }^{(10)}$. The statements were sorted for data analysis after the literal transcription of the tapes and exhaustive readings of the empirical material. Then, parts of the material were selected, seeking the relevant ideas that constitute the units of meaning. The researchers coded and sorted these units in the following themes: diabetes: shock, anger and sadness; diet plan: loss of pleasure and damage to health; medication: taking medication is tiring; healthdisease process: being healthy means being able to work. Fictitious names were used to ensure the anonymity of the participants. The project was approved by the Review Board of the Hospital das Clínicas at Ribeirão Preto Medical School on April 15, 2002 (process \#2689/2002).

\section{RESULTS AND DISCUSSION}

The results and discussion will be presented in two separate parts. The characterization of the subjects is present in the first (table \#1) and the themes identified during content analysis of the interviews in the second.

Table \#1 - Socio-demographic characterization, time since diabetes diagnosis and type of treatment used for diabetes control. Ribeirão Preto, SP, 2003

\begin{tabular}{|c|c|c|c|c|c|c|c|c|}
\hline Characterization & Maria & Joana & Nair & Laura & Ana & Lucia & Vera & Claudia \\
\hline Age (years) & 54 & 66 & 63 & 65 & 62 & 76 & 49 & 65 \\
\hline Marital status & Divorced & Widowed & Widowed & Married & Widowed & Married & Married & Widowed \\
\hline Education & $4^{\text {th }}$ grade & $1^{\text {st }}$ grade & $4^{\text {th }}$ grade & $2^{\text {nd }}$ grade & $2^{\text {nd }}$ grade & $2^{\text {nd }}$ grade & $2^{\text {nd }}$ grade & $3^{\text {rd }}$ grade \\
\hline Occupation & Housewife & Housewife & Retired & Housewife & Housewife & Retired & Janitor & Housewife \\
\hline Time since diabetes diagnosis (years) & 16 & 30 & 11 & 20 & 23 & 6 & 1 & 8 \\
\hline Monthly family income (reais) ${ }^{*}$ & 200 & 200 & 200 & 500 & 340 & 400 & 640 & 580 \\
\hline Diabetes medication & Oral use & $\begin{array}{c}\text { Insulin +Oral } \\
\text { use }\end{array}$ & Oral use & $\begin{array}{l}\text { Insulin + } \\
\text { Oral use }\end{array}$ & Insulin & Insulin & Oral use & Insulin \\
\hline Amount of other medications being used & 6 & 2 & 4 & 4 & 2 & 2 & 2 & 7 \\
\hline
\end{tabular}

Minimum wage at the time of study: R\$200 per month

The women had a maximum of four years of formal education and a maximum monthly income of nearly three times the minimum wage. As for their occupation, five were housewives, two were retired and only one was regularly employed. As such, they are characterized as belonging to a low-income socioeconomic level. Literature shows that insufficient education and lower income are associated to poor access to information and technology for diabetes control, besides restricting the patients' perception about their own condition ${ }^{(11)}$.
Diabetes: shock, anger, sadness

Being affected by a chronic disease involves several changes in habits and in everyday life, which might be extremely painful and difficult to accept. Receiving the diagnosis of a chronic disease like diabetes arouses several feelings, emotional reactions and fantasies, which healthcare professionals need to address and understand.

These behaviors are related to a series of feelings which the whole team needs to understand. Therefore, information about the emotions triggered 
by diabetes is fundamental for the disease to be followed with proper treatment ${ }^{(12)}$. In the women under study, the diabetes diagnosis was accompanied by feelings of sadness, anger, rage and shock. Ah, I was very upset (Maria). I was really shocked, really sad (Vera).

Several years after being diagnosed, distancing (being unconcerned about the disease) showed up frequently in the interviews. It's normal for me now, for me it's just like someone who doesn't have diabetes (Ana). I pretend I don't have anything (...) I live my life as if I didn't (Lucia).

The subjects experienced negative effects in view of the restrictions, limitations and possible complications posed by diabetes. Since they are not able to cope with so many restrictions carried with negative feelings all the time, they made use of the psychic mechanism of denial as an escape valve, seeking to relieve their anxiety.

In the capitalist society, people who get ill cannot stay ill for long, which means that illness is a state that can only be socially tolerated for a short period of time. Therefore, the patients may deny their disease, and since diabetes is a disease without symptoms or pain, this may favor such a reaction ${ }^{(13)}$.

The interviews revealed the influence of emotions the women experienced in treatment and disease control. The decisions regarding treatment of such a condition affect and are affected by feelings, thoughts, values and other psychosocial aspects associated to the disease. Now, if you're gonna get upset (...) that thing of being upset, then, sometimes you don't take the medication as you should, don't follow the diet correctly (Laura). When you're nervous, you open the fridge all the time (...) you eat more when you're anxious (Maria).

The statements also exposed a relation between the behavior of not adhering to the treatment and giving up on life. My brother is 80 years old, but he goes for walks. You know, he wants to live. Now me, I don't want to live anymore, he does (...). He says he doesn't drink anything with sugar in it, he doesn't drink sodas, doesn't eat cake (...). When he told me, I was eating all that stuff (Claudia).

From the testimonies, the desire to live and stay keep healthy can be inferred in cases of established diseases. Desire and commitment to life are important elements to treat diseases ${ }^{(14)}$. Diabetes influences all dimensions of patients' day-to-day, from the most trivial routines to the desire to keep on living and preserving their quality of life.

Since diabetes is a disease without cure, it needs commitment to drug therapy, diet and physical activity, and requires people to be able to cope with it for the rest of their lives. Commitment to follow or the desire to interrupt treatment, even for a short period of time, is always present in patients' daily reality.

Diet Plan: loss of pleasure and damage to health

A complex system of values, symbols and meanings is associated to the alimentary dimension. Eating goes much beyond the ingestion of nutrients and should be considered away from the biological perspective ${ }^{(15)}$. For the women in this study, following the recommended diet plan seems to have several meanings, such as the loss of the pleasures of eating and drinking, loss of autonomy and the freedom to choose the food they desire, as well as several other restrictions, as observed in the statements: I'm not the way I was anymore, without this stupid diabetes. (...) everything we eat, we think, I'm not eating this because it'll be bad for me. (...) It doesn't seem like it, but everything changes (Laura). If you're struck by this disease, the pleasure of eating and drinking is over. (...) It really messes up our lives. (...) There's no freedom anymore (Ana).

Therefore, it can be seen that, for the lowincome women in this study, diabetes imposes a series of rigid rules and regulations. It is a capricious disease, which prescribes what and how to eat, making it difficult to exert control over their own lives. Considering the extremely limited conditions they live in, in terms of resources and purchasing power, conceiving a diet plan as a requirement that produces several restrictions diminishes opportunities for pleasure and leisure even more, which are already reduced by their own social condition ${ }^{(16)}$.

The recommended diet plan seems to be related to damages to health in the interview below. The man doesn't eat anything, he's worse, he looks as yellow as that wall over there. We can't take it, we can't even stand up if we follow the diet (Ana).

In low-income classes, eating is related to work capacity; therefore, it is believed that the body needs to ingest large amounts of food to maintain an adequate work performance ${ }^{(17)}$. Lower intakes of food relates to feeling weak, feeble and sick. Physical feelings are experienced more or less intensely according to the social class people belong to. Lowincome classes tend to associate feelings of "being satisfied" to a fat-rich, high-calorie meal. Low-income women tend to use bacon and pork lard in their 
cooking more often than women in high-income classes $^{(7)}$. The expressions "You look so fat", "strong", are frequently used to refer to a person that looks healthy.

Besides, representations of obesity are experienced in different ways within the several social classes. Whatever women from a low-income social class define as a desirable weight is considered overweight according to scientific criteria and to highincome social classes ${ }^{(16)}$. In low-income social classes, a skinny person is perceived as sickly and unfit for work. As such, there is a popular expression "an empty sack will not stand up on its own", very widespread in Brazil.

Transgression and the desire to eat were present in the following excerpts: I eat sweets every day (...) When I can't find something sweet to eat, I'll eat sugar (Maria). The eyes see it, the mouth wants it (Joana).

The absence of symptoms and financial aspects in purchasing food are aspects that make it difficult to follow the diet plan, as observed: $I$ can eat anything, I don't feel anything (...) diabetes goes up, we don't get to know about it (...) so it means that it stays the same. (...) That's when I feel, well, there's no problem (Joana). For us, with a financial situation that doesn't help things, it's hard to do the $\operatorname{diet}($ Maria).

The results of the study showed that the cultural issues, knowledge, representations of the disease and values strongly influence diet behavior. The financial situation should also be considered, but it does not seem to be a determining factor for difficulties in following the adequate diet patterns prescribed for diabetes control. The patients may have scarce financial resources and still be able to select food that contributes to the improvement of their metabolic control. As such, it is evident that the diet behavior is complex and needs to be understood through interdisciplinary knowledge, comprehending its biological, social, cultural, environmental, psychological and economic aspects, especially regarding people without easy access to information, such as the low-income women in this study.

Medication: taking medicine is tiring

The person may become tired of living as a chronic patient, a situation that is confirmed and emphasized by the use of medication. According to the excerpts below, taking oral medication may cause discomfort, since it reminds the patients that they are diabetic. The negative feelings triggered may lead them to stop, forget or avoid the drug treatment. Today I'm not taking it, I'm tired of this medicine (Nair). I knew I had to take it, but I didn't because I felt sick of it (Claudia). I didn't take it everyday, I'd forget it (Ana). Damn this medicine that's worth nothing (...) Too much of a pain in the neck, taking it (Maria).

Data showed greater difficulties to accept insulin use, which seems to be associated to dysphoric feelings. On the other hand, insulin was considered effective, with quick effects and important to avoid the complications of diabetes. I didn't want to accept it at all, but there was no way (Ana). I got sick of getting injections (...) Sometimes you feel sick and sometimes you forget it. (...) I spent two or three days there without insulin, I hadn't taken it, guess I was careless (Lucia). I was upset, you know, it's really serious (Claudia). If I hadn't taken insulin I could have gone blind (Ana).

Diabetes patients' medication use is an ambiguous symbol, containing ambivalent social representations. If, on the one hand, it constantly reminds patients that they are ill, on the other hand it warrants the continuity of life and the silence of the disease ${ }^{(13)}$.

Adherence to drugs also depends on social representations about the healthcare service - either public or private - where the medication will be acquired. I was taking the white pills I got at the drugstore, and I was taking this one right. Those I got from the health station, those I wouldn't take them right. (Claudia).

The relationship between patients and healthcare professionals seems to interfere in medication intake, i.e. acceptance and use of medication are linked to faith in the doctor and healthcare services. Trust in the physician contributes to representations related to medication efficiency ${ }^{(15)}$. A widespread distrust in physicians and public healthcare has been noted. As such, the daily nonuse of medication available for free may be related to the population mistrusting whatever is public and free.

Health-disease process: Health means being able to work

The statements below show a predominance of health representations intimately associated to work capacity. I think that the person must be healthy, must have the disposition for anything, you know, everything, like, taking care of the house, taking care of everything (Joana). Health is very good, when you're healthy you're able to work (...) I have to work, I have to be healthy, right? (Vera). 
For low-income population groups, being ill means losing the only resource available for their survival: their own bodies. Health ensures the condition of keeping oneself active and, in turn, allows the satisfaction of some basic needs, such as eating and housing.

Most of the women interviewed performed unpaid activities in their own homes, undergoing an exhaustive, non-stop work routine from Sunday to Sunday. Therefore, one representation the diabetic women share is: "A woman cannot get sick", since they frequently play the role of family supporters, often being overloaded with household chores focused on the welfare of their family members, and quite often to the detriment of their own well-being ${ }^{(18)}$.

For diabetic women, health means their own work capacity, since this is responsible for the survival of their family members. Work seems to have a vital importance in the context of poverty and deprivation of material comfort. Thus, actions related to healthcare may be performed especially when the disease starts to affect their work capacity. This happens because of the economic need not to interrupt their work activities, and also because of the lower expectations held about healthcare ${ }^{(15)}$. Attention to the body becomes important only when the productive capacity is reduced, which normally is manifested in the form of symptoms, reflecting in losses for the execution of daily tasks ${ }^{(16)}$.

A study performed in Mexico found that the main concern in low-income social classes is to be able to satisfy the most urgent needs, such as having food to eat ${ }^{(19)}$. Therefore, diabetes becomes a secondary issue and a minor problem in the face of other problems present in poverty situations.

For diabetic women, pain is one of the symptoms that entail serious discomfort, because it hampers their productivity. This causes them to associate pain to disease. Diabetes makes you feel no pain, no anxiety, you feel nothing (Nair). Quite often, being ill is associated to a painful process, since pain unsettles individuals' organic balance. Some people do not consider themselves ill if they do not feel any pain.

Nevertheless, diabetic women mentioned an absence of symptoms when their glycemic levels were high, which makes it difficult to adhere to the established treatment. It was 665, I didn't feel a thing. I was cooking, doing the laundry, looking after the children, the usual (Ana). Sometimes I don't pay attention, sometimes I don't feel anything (Lucia). Daily activities can be performed normally, without noticing that glycemy is high. That means that diabetes is a disease that usually does not hamper the individual's work capacity ${ }^{(6)}$.

Having diabetes requires more attention and also a closer look at one's own body. People in lowincome social classes give less attention to their own bodies, since they use their bodies intensely at work and do not "have time to listen to themselves" ${ }^{(7)}$. The signs of disease are ignored because it is necessary to believe that everything is working well, since survival depends on being able to work for a living. This process is most commonly brought out by the poor financial conditions low-income people live in, since they depend on their own physical integrity to preserve their position in the capitalist production mode as productive agents who survive by selling their own work capacity ${ }^{(14)}$.

For low-income diabetic women, the condition of being ill is only perceived when there is a bodily manifestation that prevents them from performing their daily tasks. Therefore, for diabetic women, adhering to treatment only happens when there are objective signs. This is extremely serious, because it can compromise several organs in the medium- and long-terms - chronic complications - damaging their quality of life. As such, the painful process and symptoms of diabetic women are linked to a social representation that disease is only manifested through work capacity. Lack of attention to their bodily dimension may be due to the fact that the establishment of a reflective relationship with their own bodies is not compatible with intense physical use $^{(7)}$.

\section{FINAL CONSIDERATIONS}

The study of the representations of the health-disease process in low-income diabetic women showed that diabetes is related to negative feelings, such as shock, anger and sadness. Paradoxically, the diet plan is shown to be linked to loss of pleasure and damages to health. Similarly, diabetic women showed an ambivalent relation towards medication use, perceived as tiring and, at the same time, as something that promotes well-being and improvements in quality of life. The negative representation of healthcare services seems to interfere in adherence to drug treatment. 
The central nucleus of the social representation of health is based on the preservation of work capacity, which is related to survival of individuals and their families in low-income social classes. Therefore, the disease only acquires a representational status for these women when the symptoms interfere in the performance of their activities.

\section{REFERENCES}

1. Diabetes Control and Complication Trial Research Group DCCT. The effect of intensive treatment of diabetes on the development and progression of long-term complications in insulin - dependent diabetes mellitus. N Engl J Med 1993; 329:977-86

2. United kingdom prospective diabetes study group - ukpds Group: UK prospective study 17: a nine-year update of randomized, controlled trial on the effect of improved metabolic control on complications in non-insulin dependent diabetes mellitus. Ann. Intern Med 1998; 124:136-45.

3. Mazze R, Weaver T, Upham P, Simonson G, Bradley R, Sundem $S$, Kiefver R, Gordon T. Staged diabetes management - decision support (SDM-ds): an internet-based system for clinical decision making. Diabetes Res Clin Practice 2000; 50(suppl): 196

4. Assal JP, Berger M, Canivet J. History and aims of the diabetes study group. Amsterdam, Netherlands. Excerpta Medica $1982 ; 1: 3-7$.

5. Oliveira FJA. Concepções de doença: o que os serviços de saúde têm a ver com isso? In: Duarte LFD, Leal OF, organizadores. Doença, sofrimento, perturbação: perspectivas etnográficas. Rio de Janeiro (RJ): Fiocruz; 1998. p. 81-94. 6. Torres-López TM, Sandoval-Díaz MS, Pando-Moreno M. Sangre y azúcar: representaciones sobre la diabetes de los enfermos crônicos en um barrio de Guadalajara, México. Cad. Saúde Pública 2005 janeiro; 21(1):101-10.

7. Boltanski L. As classes sociais e o corpo. $3^{a}$ ed. Rio de Janeiro (RJ): Graal; 1989.

8. Laplantine F. Antropologia da doença. $1^{\text {a }}$ ed. São Paulo (SP): Martins Fontes; 1991.

9. Moscovici S. A representação social da psicanálise. Rio de Janeiro (RJ): Zahar; 1978.

10. Minayo MCS. O desafio do conhecimento: pesquisa qualitativa em saúde. 7a ed. São Paulo (SP): Hucitec; 2000. 11. Takahashi ITM, Almeida HGG, Guariente MHDM, Garcia CLL, Haddad MCL, Takahashi OC et al. Perfil dos diabéticos assistidos em duas unidades básicas de saúde de Londrina PR. Diabetes Clínica 2001 março-abril; 5(2):122-8.
Therefore, behaviors related to self-care are strongly marked by representations which the whole healthcare team needs to understand. Identifying the social representations of the health-disease process makes it possible to know how these women recreate the scientific knowledge made available through communication means by associating it with popular knowledge, which allows them to appropriate the experience of illness and treatment.

12. Santos ECB, Zanetti ML, Otero LM, Santos MA. O cuidado sob a ótica do paciente diabético e de seu principal cuidador. Revista Latino-am enfermagem 2005 maio-junho; 13(3):397406.

13. Lefèvre F. O medicamento como mercadoria simbólica. São Paulo (SP): Cortez; 1991.

14. Berlinguer G. A doença. São Paulo (SP): Hucitec; 1988. 15. Helman CG. Cultura, saúde e doença. $2^{a}$ ed. Porto Alegre (RS): Artes médicas; 1994.

16. Garcia RWD. Re(a)presentações da obesidade nas classes sociais. Rev Alimentação \& Nutrição 1989; 9:42-46.

17. Campos MS. Poder, saúde e gosto. São Paulo (SP): Cortez; 1982.

18. Witt RR. Gênero e diabetes: implicações para o autocuidado. In: Lopes MJM, Meyer DE, Waldow VR, organizadoras. Gênero e saúde. Porto Alegre (RS): Artes Médicas; 1996. p. 150-156.

19. Martínez FJM. Enfermedad, cultura y sociedad: la identidad cultural de las personas com diabetes del sector informal urbano. Cuadernos Médico Sociales 1992; 61:49-61. 